\title{
Identification of zones of preferential groundwater tracer transport using a mobile downhole fluorometer
}

\author{
Raymond M. Flynn • Pierre-Andre Schnegg • \\ Roberto Costa • German Mallen · François Zwahlen
}

\begin{abstract}
A mobile downhole fluorometer was used to detect zones of preferential groundwater tracer transport into an observation well. Identification of such zones is not possible if individual samples are collected over the well's entire screened interval. Laboratory-based tests using the fluorometer, and a purpose-built apparatus demonstrated that the fluorometer could be used with tracers to characterise well water flow regimes. During field investigations in a porous aquifer, the fluorometer monitored tracer concentrations in an observation well with a 12-m-long screen, $10 \mathrm{~m}$ down the hydraulic gradient from a fully penetrating injection well. Test results showed that the tracer occurred in the observation well over a discrete 2.5 -m-thick interval. Single-well dilution test and vertical-flow data indicated that water entered the well at additional depths, but no tracer was detected at these levels. A numerical model reproducing dilution test concentration profiles indicated that water entered the well in many of these horizons at comparable velocities to those in the tracer-bearing zone. These data suggest that groundwater flow direction varied with depth in the aquifer under investigation. Moreover, simulations of tracer arrival indicated that the tracer distribution observed in the observation well was derived from a horizon that may be no thicker than $0.5 \mathrm{~m}$.
\end{abstract}

Received: 19 March 2003 / Accepted: 3 August 2004

Published online: 8 December 2004

(C) Springer-Verlag 2004

R. M. Flynn $(\bowtie) \cdot$ F. Zwahlen

Hydrogeology Centre,

University of Neuchatel,

Emil Argand 11, 2007 Neuchatel, Switzerland

e-mail: ray.flynn@unine.ch

P.-A. Schnegg · R. Costa

Geomagnetism Group, Geological Institute,

University of Neuchatel,

Emil Argand 11, 2007 Neuchatel, Switzerland

G. Mallen

Department of Hydrology,

Gesellschaft für Strahlenforschung,

Ingoldstäter Landstrasse 1, 85764 Neuherberg, Germany
Résumé Un fluorimètre a été utilisé pour détecter les zones d'écoulement préférentiel d'un traceur dans un puits d'observation. Les identifications de telles zones n'est pas possible si les échantillons individuels sont collectés sur toute les longueurs des parties crépinées du puits. Les tests de laboratoire utilisant un fluorimètre et un dispositif adéquat ont montré que les fluorimètres pouvaient servir à définir les régimes d'écoulement de l'eau dans les puits. Durant les investigations de terrain dans un aquifère poreux, le fluorimètre a enregistré les concentrations du traceur dans un puits d'observation avec une crépine de $12 \mathrm{~m}$. de long, $10 \mathrm{~m}$ sous le gradient hydraulique dans un puits à pénétration totale. Les résultats des tests ont montré que le traceur apparaissait dans un interval discret de $2.5 \mathrm{~m}$ de long. Un test de dilution en puits unique et des données d'écoulement vertical ont indiqué que l'eau rentrait dans le puits à d'autres profondeurs, mais le traceur n'a pas été détecté à ces niveaux. Un modèle numérique reproduisant le test de dilution et le profil de concentration a indiqué que l'eau entrait dans le puits à ces niveaux à des vitesses comparables de celle du traceur. Ces données suggèrent que l'écoulement des eaux souterraines varie avec la profondeur dans l'aquifère sous la zone d'investigation. D'ailleurs, les simulations de l'arrivée du traceur ont montré que la distribution des concentrations du traceur dans le puits ne pouvaient pas être dues à une couche plus fine que $0.5 \mathrm{~m}$.

Resumen Se utilizó un fluorómetro móvil descendente para detectar zonas de transporte preferencial de trazadores de agua subterránea en un pozo de observación. La identificación de tales zonas no es posible si se colectan muestras individuales en todo el intervalo enmallado del pozo. En base a pruebas de laboratorio utilizando el fluorómetro y un aparato especial construido se demostró que el fluorómetro podría utilizarse con trazadores para caracterizar ambientes de flujo de agua en los pozos. Durante investigaciones de campo en un acuífero poroso, el fluorómetro monitoreó concentraciones de trazadores en un pozo de observación con una malla de $12 \mathrm{~m}$ de largo, $10 \mathrm{~m}$ abajo del gradiente hidráulico de un pozo de inyección que penetra totalmente el acuífero. Los resultados de las pruebas muestran que el trazador se presentó en el pozo de observación en un intervalo discreto de $2.5 \mathrm{~m}$ de espesor. Pruebas de dilución en un solo pozo y datos de flujo vertical indicaron que el agua entró al. pozo 
en profundidades adicionales, pero que no se detectó el trazador en esos niveles. Un modelo numérico que reproduce los perfiles de concentración de las pruebas de dilución indica que el agua entró al. pozo en muchos de estos horizontes en velocidades comparables a las existentes en la zona portadora de trazadores. Estos datos sugieren que la dirección de flujo de agua subterránea varió con la profundidad en el acuífero bajo investigación. Por otra parte, las simulaciones de llegada del trazador indicaron que la distribución del trazador observada en el pozo de observación se derivó de un horizonte cuyo espesor puede no ser mayor de $0.5 \mathrm{~m}$.

Keywords Porous aquifer - Tracer - Fluorometer . Observation well $\cdot$ Preferential flowpath

\section{Introduction}

An absence of sufficient geological data and complex well water flow dynamics often hinder the accurate assessment of groundwater conditions during hydrogeological investigations using wells with long screened intervals. Rushton and Howard (1982) highlighted the unreliability of open boreholes as groundwater level observation points during pumping tests. Similarly, Price and Williams (1993) noted that open boreholes are not reliable groundwater sampling points. Nonetheless, time and budget restrictions often require field hydrogeologists to use boreholes and/or wells with long screened intervals to determine hydrogeological parameters. This requirement has prompted subsequent investigations into the influence of open holes and wells with long screened intervals on water sampling and hydraulic conductivity determination (Jones and Lerner 1995; Hutchins and Acree 2000; Kaleris et al. 1995).

In terms of groundwater protection zone delineation, identification of zones of preferential flow frequently constitutes a critical aspect in the contaminant transport assessment. Tracer tests can provide important information about the variability of mass transport rates between wells (Kass 1997). However, sampling techniques as well as injection well and monitoring well construction may be highly variable from one test site to another. Typically, individual samples are collected over the entire screened interval of the well, e.g. Kennedy et al. (2001). However when individual monitoring wells are screened in deposits with variable hydraulic conductivities, groundwater flow rates in preferential flow zones can be under-estimated using this sampling technique. Consequently, as such methods fail to reflect the variation in the hydraulic properties of the deposits in contact with the well screen, the groundwater flow velocities necessary for establishing realistic aquifer protection zones around water supply wells may be inaccurately estimated. Tracer monitoring techniques may be modified for wells with long screened intervals using multiple pump systems such as level-determined groundwater sampling in open wells (Rapp et al. 1998). However, such approaches rely on extracting water from wells and so induce hydraulic gradients. Similarly,
Schirmer et al. (1995) noted that packer systems and/or low-flow sampling cannot be confidently used for water quality sampling where wells have gravel packs and vertical flow gradients. Moreover, even when vertical flow gradients are not present, the small intervals sampled with low-flow sampling techniques imply that it is possible that all preferential flow zones of interest may not be sampled.

This paper presents a method for measuring tracer concentration profiles in boreholes using a mobile submersible borehole fluorometer and dedicated programmable pulley system. This equipment has allowed zones of preferential flow supplying groundwater to wells with long screened intervals to be identified, even in wells with gravel packs and vertical flow gradients. The method may be applied to single wells where rates of fluorescent tracer dilution may be related to groundwater flow rates, or as a monitoring tool in observation wells where it may be used to identify zones of tracer arrival. Integrating both single well and observation well techniques provides insights into the well water flow regime and the behaviour of the tracer upon arrival in an observation well. These methods, their verification under controlled laboratory conditions, and their application in the field are described below.

\section{Materials and methods}

\section{Fluorometer}

All investigations employed a University of Neuchâtel Geomagnetism Group (GGUN) downhole fluorometer (sonde). The sonde (74 $\mathrm{mm}$ in diameter by $200 \mathrm{~mm}$ in length) is submersible in a water column to a depth of $70 \mathrm{~m}$. An optical cell measures fluorescent tracer concentrations of the water passing through a sampling chamber set in the centre of the sonde (Fig. 1). The sonde is capable of detecting uranine (Sodium fluorescence; excitation wavelength $491 \mathrm{~nm}$, emission wavelength $512 \mathrm{~nm}$,) to concentrations of $0.02 \mathrm{ppb}$.

A multicore cable provides the mechanical support to suspend the fluorometer in the borehole, while permitting optical cell signals to be relayed to a data logger at the ground surface. Signal data may also be observed directly in the field on a laptop computer that displays fluorometer data by means of dedicated software. This allows zones of interest in a borehole to be rapidly identified. More comprehensive details of the GGUN downhole fluorometers operation are contained in Schnegg and Bossy (2001).

\section{Pulley system}

Except where otherwise stated below, the fluorometer was adapted to allow regular measurements to be made while being continuously raised and lowered over a predetermined interval using a programmable pulley system. The pulley consisted of a programmable motor and a 


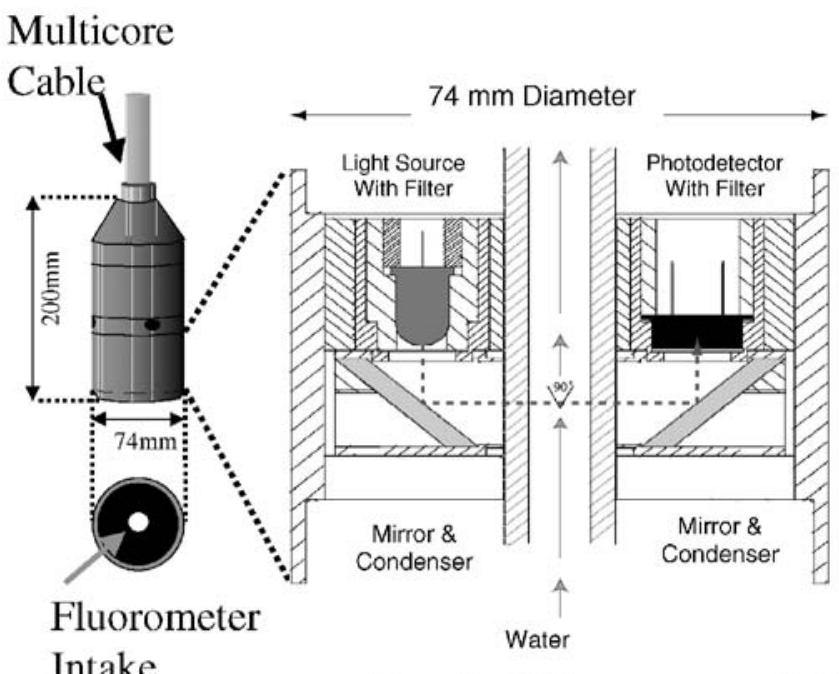

Intake

\section{Detail of Measurement Cell}

Fig. 1 Dimensions and operation of the downhole fluorometer. In the measurement cell, a mirror reflects light emitted from a light source through a condenser before passing through the fluorometers sampling chamber. The light causes fluorescence in target compounds. Fluorescence generated by the compounds passes through a filter and is detected by photodetector set a $90^{\circ}$ to the light source. The resulting signal is transmitted to the ground surface via a multicore cable

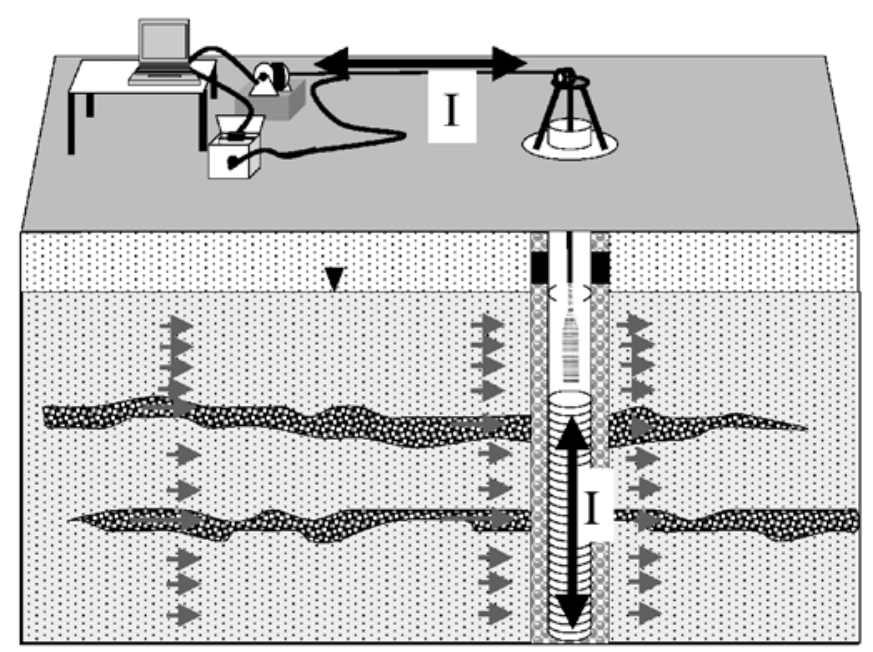

Fig. 2 Operation of the mobile field fluorometer. The multicore cable suspending the fluorometer in the borehole is attached to the programmable pulley cable. The pulley continuously releases and withdraws its cable over an interval I, which corresponds to the interval to be measured downhole

spool of 0.1-mm-thick piano wire cable set back from the borehole under study by a distance (I), which is greater than or equal to the depth interval under investigation (Fig. 2). The pulley cable is attached to the fluorometer multicore measurement/support cable using a connecting clip. To ensure ease of movement in the borehole, the downhole fluorometer was centred over the hole using a tripod with an attached roller. This arrangement allowed the multicore cable to easily slide back and forth. By

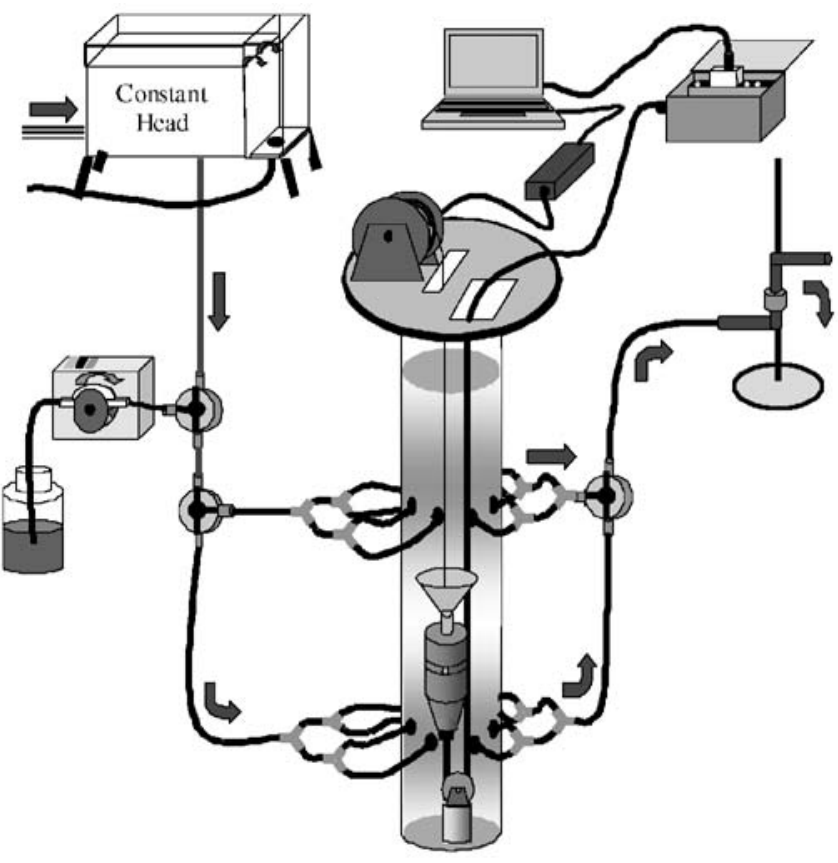

Fig. 3 Laboratory borehole apparatus operation. Broad arrows illustrate the directions of flowing water. The constant head reservoir supplies a constant flow of water through the central 6 inch $(15.24 \mathrm{~cm})$ tube (Laboratory borehole) at one or two levels. A peristaltic pump on the influent side of the apparatus allows the tracer to be injected into inflowing water to simulate tracer arrival. The inverted fluorometer measures tracer concentration profiles

releasing and withdrawing the pulley cable, the sonde could be raised and lowered in a borehole. Instructions provided to the pulley motor, via a laptop computer, specified the depth of the first measurement, the distance between the fluorescence measurements $(5 \mathrm{~cm}$ minimum) and the number of measurements that the fluorometer must make per cycle.

\section{Laboratory apparatus}

Prior to initiating field measurements, a series of laboratory-based investigations evaluated the ability of the fluorometer to detect the tracer entering or leaving a borehole via preferential flow horizons, using a purpose built apparatus (Fig. 3). The apparatus consisted of a $1.7 \mathrm{~m}$ long, 6 inch $(15.24 \mathrm{~cm})$ internal diameter (ID) Perspex tube (Laboratory borehole) with eight holes each drilled at two levels to permit water to flow through the 6-inch tube at selected levels at a constant flow rate. The downhole fluorometer pulley was placed on top of the borehole and the sonde inverted in the 6-inch tube (due to laboratory space restrictions). The fluorometer could thus measure the tracer concentration profiles in the borehole over time, while the transparent Laboratory borehole walls permitted the location of the tracer and the fluorometer in the well to be directly compared with ongoing measurements. The high flux rates investigated using the apparatus (1-100 $\mathrm{m} /$ day) resembled those observed in 
tracer tests in Swiss gravel aquifers during preliminary field-based investigations carried out at the start of this study.

A three-way valve, connected to the tubing that supplied the influent side of the Laboratory borehole, permitted water to enter via either the upper or lower set of holes, or through both. Similarly, another three-way valve on the effluent side of the borehole allowed water to leave at either or both levels. This valve system permitted the flow regime in the borehole to be controlled. Opening both sets of valves at one level ensured a horizontal flow regime. On the other hand, by permitting water to enter and exit at alternate levels, while blocking flow through corresponding tubes on the opposite side of the same level resulted in water flowing vertically, upwards or downwards, in the well, depending on the configuration used. An additional three-way valve placed on the influent line supplying water allowed tracer to be injected into water entering the borehole, thus permitting tracer arrival to be simulated.

Circulating water was maintained at room temperature throughout all experiments to prevent the formation of thermal convective cells in the laboratory borehole. Constant head reservoir temperature was verified at regular intervals using an electronic thermometer (accuracy $\left.+/-0.1{ }^{\circ} \mathrm{C}\right)$.

\section{Experimental methods}

The laboratory borehole apparatus permitted a series of investigations to be carried out to evaluate the performance of the meter in detecting tracer in a borehole under controlled conditions. Following each experiment, a pump removed all water from the laboratory borehole prior to it being refilled with fresh, tracer-free water for a subsequent experiment.

The following experiments were completed using the laboratory borehole:

1. Identification of depth of tracer occurrence. Prior to initiating experiments in which water flows through the Laboratory borehole, a series of tests were conducted using a column of still water. A peristaltic pump injected approximately $20 \mathrm{ml}$ of concentrated tracer at a known depth directly into the 6-inch $(15.24 \mathrm{~cm})$ tube, after which measurements with the mobile downhole fluorometer were initiated. Tracer concentrations were sufficiently high to be visible through the boreholes Perspex walls. A series of measurement cycles generated tracer concentration profiles in the hole. This permitted an assessment of how accurately the sonde could detect the depth of tracer occurrence. Successive measurement cycles allowed the effects of the meters movement on tracer distribution in a borehole to be established.

2. Identification of zones of preferential transport by dilution (single well dilution tests). This series of experiments investigated whether the downhole fluo- rometer could be used to identify the position of active flow zones. During the experiments the mobile downhole fluorometer measured tracer concentrations in the 6-inch tube as water passed horizontally through the active flow zones at a rate of $2 \mathrm{l} / \mathrm{min}$. Prior to initiating fluorometer measurements, a small volume of concentrated tracer was injected along the Laboratory borehole water column. The action of the laboratory apparatus resulted in tracer-bearing water being diluted with tracer-free water in the zones of active flow. This dilution process and the resulting declines in tracer concentration in the active flow zones permitted these zones to be identified in the Laboratory borehole using tracer concentration profiles generated with the mobile downhole fluorometer. Further experiments conducted at flow rates between 0.25 and $5 \mathrm{l} / \mathrm{min}$ investigated whether the results at $2 \mathrm{l} / \mathrm{min}$ were valid at other flow rates.

3. Identification of zones of tracer arrival. Injecting tracer into the influent water before it entered the 6-inch tube, while monitoring with the mobile fluorometer, allowed the meter's efficiency in detecting zones of tracer arrival to be assessed. Tracer-bearing influent water, flowing at $2 \mathrm{l} / \mathrm{min}$, entered the Laboratory borehole while the fluorometer monitored for fluorescent tracer in the boreholes water column. The tests permitted the accuracy of the fluorometer to identify the depth and concentration in zones where tracer-bearing water enters the borehole to be determined. Moreover, as with single well dilution tests described above, repeated measurements allowed the consistency of the fluorometer in identifying the depths of tracer arrival to be ascertained, while those carried out at between 0.25 and $5 \mathrm{l} / \mathrm{min}$ investigated whether similar responses were observed at different flow rates.

A further series of arrival experiments involved injecting tracer into the influent water before it entered the Laboratory borehole, where water was flowing vertically. During these experiments, the tracer solution entered the borehole at one level, but was forced to leave by flowing upwards or downwards to another level, and so the effects of vertical flow on tracer distribution could be investigated.

3. Vertical flow rate measurement. An additional series of laboratory tests investigated whether a modified fluorometer arrangement could be used to quantify vertical flow rates. The method developed involved setting the fluorometer at a fixed point in the borehole and subsequently injecting a pulse of tracer at a known distance from the meter's measurement cell. The fluorometer was set above the injection point (base facing downwards) to measure upward flow, or below the injection point (base facing upwards) to measure downward flow. Consequently, when using a single fluorometer in the field, this technique requires a measurement to be made on either side of the injection point for a given depth, i.e. two separate injections must be made with the fluorometer oriented either upward or downward in each case. However, should 
two fluorometers be available, a meter can be set at either side of the injection point, thus reducing the necessary number of injections to one.

The fluorometer data logger measured tracer concentration with time and allowed a breakthrough curve to be generated, should the tracer flow through the fluorometer cell. The centroid of the resulting breakthrough curve provided the necessary data to determine the vertical flow velocity, and thus the flow rate, in the well (Drost et al. 1968). The method was investigated using the laboratory apparatus under known vertical flow rates, and the expected results compared to those obtained.

\section{Field investigations}

Following laboratory investigations, the methods developed under controlled conditions were applied at a porous aquifer test site. The site selected to test the application of the mobile downhole fluorometer had a number of observation wells with long screened intervals and complex well water flow dynamics. Investigations carried out at the site thus permitted the application of the fluorometer to be evaluated under complex natural conditions.

\section{Site description}

The Gesellschaft für Strahlenforschung (GSF) Dornach test-site is located on the Munich Gravel Plain near the village of Dornach on the eastern outskirts of Munich, Germany (Fig. 4). Available well construction diagrams/ drilling records for the site indicate that it is underlain by approximately $14 \mathrm{~m}$ of Quaternary sands and gravels. These deposits overlie Tertiary sands and silts (Müller and Seiler 2001). Seiler (1988) reported the gravels to have hydraulic conductivities of the order of $5 \times 10^{-1} \mathrm{~cm} / \mathrm{s}$, with hydraulic gradients of the order of $0.005-0.01$ across the site. The test-site consists of seven wells set in a $20-\mathrm{m}-$ wide semicircular array with an eighth well in the centre equidistant from the other wells. The wells B1, B7 and B8 were used in this study. These wells have 12-m-long screened intervals that fully penetrate both upper and lower Quaternary sands and gravels (Fig. 4). Groundwater level measurements at the site indicate that the water table fluctuates between approximately 1 and 3 metres below ground surface (mBGS).

Previous comparative tracer testing at the Dornach test site using uranine in conjunction with heavy metals tracers (Muller and Seiler 2001), cadmium and arsenic (Zahn and Seiler 1992), showed that tracers are transported from the 2-inch-internal diameter (ID) injection well (B1) to the 8 inch ID observation well (B8) and the 2 inch ID well (B7). During these tests, the whole-well circulation method was employed, whereby water from the bottom of the observation wells was pumped to the surface to flow through on-line meters for monitoring of selected parameters. After passing through the monitoring system, the water was reinjected into the well at the water
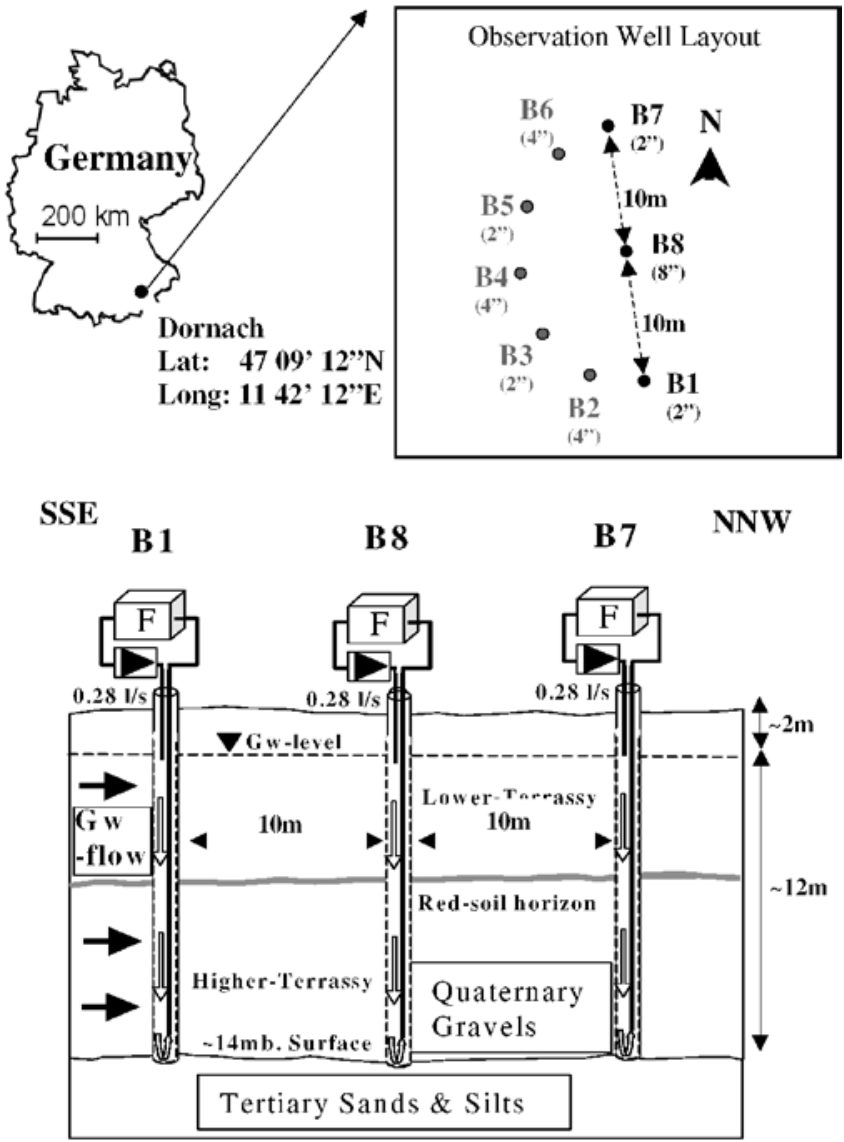

F- On-line Fluorometer $\checkmark$ - Circulation Pump

Fig. 4 Site location map (with wells used in tests shown in bold type) and geological cross section with setup for whole well tests, Dornach Test Site. Well diameters in inches, 1"=2.54 cm (modified from Müller and Seiler, 2001)

table. The whole-well approach maintained a static water level, while demonstrating mass transport routes between the injection well and observation wells. While demonstrating hydraulic connection between the injection point and observation wells, it is noteworthy that this monitoring method fails to permit identification of the depth(s) of tracer arrivals in observation wells.

During the current study, a series of additional tracer tests further examined transport between injection well, B1, and observation well, B8 with the purpose of defining the depths at which the tracer entered monitoring well. During these tests, uranine acted as a solute tracer. Kass (1997) summarised the results of a number of previous tracer tests using uranine carried out at a variety of locations, and concluded that the tracer is not retarded by aquifer materials relative to other conservative tracers, once significant quantities of organic matter are absent. Moreover, comparative tracer tests carried out at the Dornach site using uranine and bromide showed no significant difference in arrival time between the two tracers.

The suite of tracer tests carried out at the Dornach test site allowed the applicability of the downhole fluorometer 
as a tool in tracer testing to be assessed. In all tests, the tracer was circulated across the screened interval of the injection well using the whole-well recirculation technique.

Prior to carrying out investigations with the downhole fluorometer, two tests were carried out whereby tracer concentrations were monitored in observation wells B7 and B8 using whole well sampling techniques (circulating at approximately $10 \mathrm{l} / \mathrm{min}$ in both wells). These tests were carried out in May 2000 (Whole well test \#1) and July 2001 (Whole well test \#2). Subsequent to these tests, a pair of additional investigations carried out using low flow sampling techniques examined the variation in breakthrough curves at different depths in monitoring well B8 in August 2002. One test (Low flow \#1) investigated tracer response at four equally spaced intervals, while the other test (Low flow \#2) sampled zones identified as containing tracer according to downhole fluorometer test results.

Two tracer tests used the mobile downhole fluorometer to examine tracer concentration profiles with depth in B8 following uranine injection in B1. Downhole \#1 was carried out in July 2001 and a subsequent test, Downhole \#2 was carried out in August 2002. Both tests monitored tracer concentrations in the interval from 3 to $14.5 \mathrm{mBGS}$ at half-hourly intervals for the first $12 \mathrm{~h}$ after injection and again at $24 \mathrm{~h}$ after injection.

Single well dilution testing, completed following the end of Downhole \#2 when the tracer could no longer be observed in observation wells, was carried out at B8 to more fully characterise its well water flow regime. Triplicate single well dilution tests initiated at hourly intervals measured uranine concentrations over the screened interval of the well, starting approximately 4 min after the tracer was injected in the same manner as used in the laboratory experiments.

Following the single well dilution tests, vertical flow measurements of upward and downward flow component of well water flow in B8 were completed at $0.5-1 \mathrm{~m}$ intervals along the screened interval using the technique developed in the laboratory. An injection line set between 25 and $50 \mathrm{~cm}$ from the fluorometers sampling chamber permitted approximately $200 \mathrm{ml}$ of $50 \mathrm{mg} / \mathrm{l}$ uranine to be pumped into the water column over a $30-\mathrm{sec}$ interval during each measurement. Tracer monitoring continued for 15-50 min after each injection pulse. Both vertical flow testing and single well testing were completed within two weeks of the Downhole \#2 test.

\section{Modelling}

In order to further understand tracer response in well B8 at the Dornach test site, a numerical model incorporating vertical flow test data and single well dilution test data was developed based on a tracer mass balance and the principal of conservation of well volume. The goal of the model was to simulate the concentration profiles observed in the observation well during dilution tests and, using the (a) Conditions at time $\mathrm{t}$

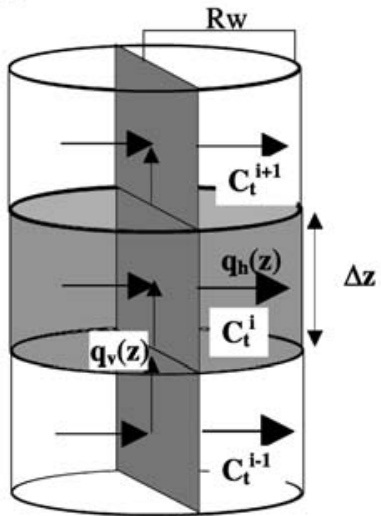

Horizontal flow Component: (b) Conditions at time $t+\Delta t$

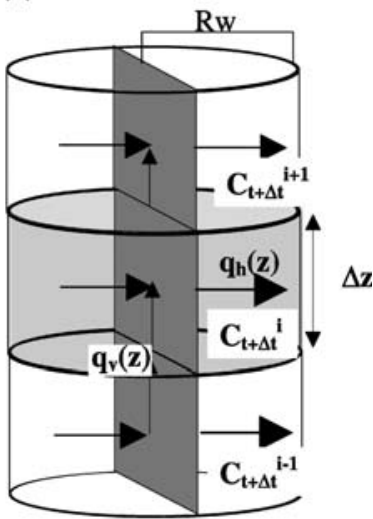

Vertical flow Component:

$C_{t+\Delta t}^{i}(z)=C_{t}^{i}(z)-\frac{2 q_{h}(z) \Delta t C_{t}^{i}}{\pi R_{w}} \quad C_{t+\Delta}^{i}(z)=C_{t}^{i}(z)-\frac{q_{v}(z) \Delta\left(C_{t}^{i+1}-C_{t}^{i-1}\right)}{\Delta z}$

Concentration at end of time step= Concentration at Start Loss due to horizontal flow - Loss due to vertical flow.

Fig. 5 Schematic illustration of mass balance modelling of single well dilution test data. Decline in tracer concentration in a cell of thickness $\Delta z$ during a time step $\Delta t$ results from tracer removal by vertical flow across the cell, $q_{\mathrm{v}}(z)$ and by horizontal flow, $q_{\mathrm{h}}(z)$ into the aquifer. No tracer can enter the well from up-gradient, nor can tracer enter from the top or base of the water column. The final analytical version of this derivation reduces to Eq. (2)

resulting calibration data, investigate whether the breakthrough curves observed during the Downhole \#2 test could be generated.

The fundamental mass-balance equation for the model states

$\frac{\partial M}{\partial t}=\mathrm{V} \frac{\partial C}{\partial t}$

where $M$ is the tracer mass (M); $C$ is tracer concentration $\left(\mathrm{ML}^{-3}\right) ; V$ is the volume of tracer $\left(\mathrm{L}^{3}\right) ; t$ is time $(\mathrm{T})$.

This may be expressed in terms of the vertical and horizontal fluxes that remove injected tracer from a segment of a well as follows:

$\frac{\partial C}{\partial t}=-\frac{2 q(z)_{\mathrm{h}}}{\pi r_{\mathrm{w}}} C(z)-q(z)_{\mathrm{z}} \frac{\partial C}{\partial z}$

where $q(z)_{\mathrm{h}}$ is depth-dependent horizontal specific flux leaving the well $\left(\mathrm{LT}^{-1}\right) ; z$ is depth from water table $(\mathrm{L})$; $r_{\mathrm{W}}$ is the well radius $(\mathrm{L}) ; q(z)_{\mathrm{z}}$ is the depth-dependent vertical specific flux flowing through the well $\left(\mathrm{L} / \mathrm{T}^{-1}\right)$.

Moreover, since $\mathrm{V}$ for each cell remains constant.

$\frac{\partial Q_{h}}{\partial t}+\frac{\partial Q_{z}}{\partial t}=0$

where $Q_{\mathrm{h}}$ is the horizontal flow rate $\left(\mathrm{L}^{3} \mathrm{~T}^{-1}\right) ; Q_{\mathrm{z}}$ is the vertical flow rate $\left(\mathrm{L}^{3} \mathrm{~T}^{-1}\right)$.

Figure 5 illustrates the application of this model to a discretised segment of a well screened interval displaying vertical and horizontal well specific flux components.

Using this approach, the water column in B8 was discretised into 0.25-m cells. Applying Eq. (2), values of 
$q(z)_{\mathrm{h}}$ and $q(z)_{\mathrm{z}}$ were varied for each cell to reproduce the variation in $C(z)$ observed by coupling flow rates and concentrations in adjacent cells to one another.

Linear interpolation between vertical flow measuring points allowed a vertical flow rate to be assigned to each cell. The observed values of $C(z)$, obtained from downhole fluorometer measurements were averaged over five measurement increments during dilution tests. Model simulations used time steps that allowed no more than 1/ 20th of a cell volume to pass through a cell during each time step to limit numerical dispersion effects. Finally, all concentrations were expressed relative to those observed at 4.0 mBGS. Concentrations at this level remained constant between measurements started $4 \mathrm{~min}$ after injection and those observed after $30 \mathrm{~min}$. (residual tracer was pumped from this zone following these measurements, prior to test repetition).

\section{Calibration}

Model calibration was carried out iteratively by varying vertical flow rates from their calculated value within the proportions calculated, based on measurements using the Laboratory borehole, while simultaneously adjusting horizontal specific fluxes to reproduce the tracer dilution profile observed in B8. According to Eq. (3), variations in the vertical tracer flux $q(z)_{\mathrm{Z}} C$ needed to be accounted for by horizontal flux $q(z)_{\mathrm{h}} C$ in each well screen segment. This permitted an additional constraint to be applied to the model since the horizontal flux could not be negative, as this would require that additional tracer was added to the system from outside the well during simulations. Additional constraints involved applying a horizontal flow regime at those well screen segments in contact with the water table and at the base of the aquifer, where water cannot enter the water column from above and below respectively. Other horizontal flow zones, within the water column, were either classified as convergent flow zones or divergent flow zones. Convergent flow zones receive water vertically from adjacent cells, while divergent flow zones discharge water to adjacent cells.

Following calibration, the well water flow regime, as determined by the model, was used to simulate tracer arrival in the borehole. Comparison with observed fluorescent tracer arrival data, reaching B8 from B1, acted as a means of verifying that the observed model parameters were sufficiently realistic. Arrival was simulated by maintaining a constant concentration at a zone of tracer arrival, while running the model over the time required to measure a tracer profile in the well's water column. The time period was sufficiently short $(10 \mathrm{~min})$ such that the tracer concentration at the point of arrival could be considered essentially constant, based on existing breakthrough curves. The location and thickness of the horizon supplying tracer to the borehole were selected based on qualitative observations of tracer concentration profiles made during the laboratory-based experiments.

\section{Results \\ Laboratory testing}

The results of the tracer tests using the Laboratory borehole demonstrated that the fluorometer could be used to determine the depth of tracer occurrence with an accuracy of plus or minus $20 \mathrm{~cm}$. Although the fluorometer moves continuously, inefficient flow through the sampling chamber results in water not being fully flushed as the fluorometer advances. This results in liquid being retained by the meter. This liquid is subsequently released and enters the fluorometer measurement cell during later measurements. Consequently, upon encountering a tracer bearing zone in a well, true tracer concentrations must be regarded as possibly being greater than those measured, since tracer-free water may be released from the temporary stagnation zones to dilute the tracer in the sampling chamber. Conversely, tracer entering the fluorometer is incompletely flushed and can be released at a later time to suggest that low concentrations of tracer occur in tracerfree zones. Under the hydrodynamic conditions employed, laboratory tests suggest that residual quantities of tracer encountered at a particular level may be released up to $20 \mathrm{~cm}$ above or below the level where it is first encountered in a measurement cycle.

In addition, measurements made during successive cycles of tracer experiments demonstrated that the action of the sonde in the 6-inch tube tends to result in redistribution of the tracer. This process leads to homogenisation of the tracer with tracer-free water, if there is no zone of active flow through the Laboratory borehole.

The results of the single well dilution experiments indicate that the downhole fluorometer is capable of identifying zones of preferential flow. Figure 6a shows that when flow is purely horizontal, the lowest tracer concentrations observed during well dilution tests are consistently in the zones of active flow. This occurs despite homogenisation, due to the action of the sonde passing through the measurement interval. Similarly, Fig. $6 \mathrm{~b}$ presents the results of a typical tracer arrival test. The figure shows that when measurements are made of the tracer concentration entering the Laboratory borehole, concentrations are greatest in zones of active flow. In contrast to dilution tests, the peak occurs consistently around the zone of tracer arrival.

Tracer distribution patterns are more complex when a vertical flow regime operates in the borehole. In this case, the tracer is advected vertically by the water entering the borehole. This process results in the tracer spreading out to occupy the thickness across which vertical flow occurs (Fig. 6c). Despite this phenomenon, it is noteworthy that the highest tracer concentrations during tracer arrival experiments occurred consistently around the inflow zone. Moreover, the marked concentration decline associated with the outflow zone (within the range of measurement error) shows that the fluorometer is capable of detecting the zone where the tracer leaves the well. Nonetheless, should vertical flow be neglected in these 
(A) Uranine Conc (ppl)

(B) Uranine Conc

(C) Uranine Conc (ppb)

$\begin{array}{llll}0 & 5 & 10 & 15\end{array}$

$\begin{array}{llll}0 & 5 & 10 & 15\end{array}$

$\begin{array}{llll}0 & 200 & 400 & 600\end{array}$

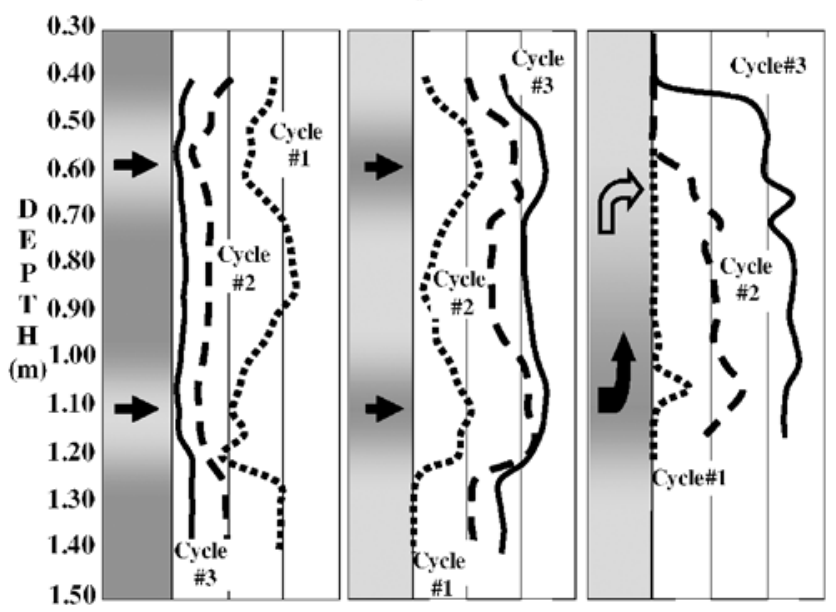

Fig. 6 Summary of the results of tracer tests using the Laboratory borehole. The grey shading on the left hand side of each plot indicates the distribution of tracer in the apparatus. Dark grey represents zones of high tracer concentration. Light grey indicates zones of low concentration. Heavy arrows indicate flow directions. a Tracer dilution test. b Tracer arrival test. c Tracer propagation with vertical flow (no further propagation after cycle \#3). All uranine concentrations are in $\mathrm{ppb}$

circumstances in the field, concentrations measured by the fluorometer would suggest that the tracer arrives in a thicker horizon than it actually does. Consequently, if tracer behaviour in boreholes is to be adequately char- acterised, the influence of vertical flow on tracer distribution must be assessed. These results, obtained at $21 / \mathrm{min}$ are representative of those obtained over the range of flow rates investigated.

Experimental breakthrough curves generated during vertical flow tests carried out using the Laboratory borehole indicate that this measurement method can underestimate vertical flow rates by up to $30 \%$ when using the centroid time to calculate velocity. Nonetheless the experimental results show that the downhole fluorometer may be used to characterise both the magnitude and direction (upward or downward) of water flow in a borehole. This approach offers a practical alternative to other methods of vertical flow testing, such as heat pulse or impeller flow meters in fast flowing systems where the tracer is rapidly removed from the borehole.

\section{Field tests}

The results of the whole-well tracer tests at the Dornach test site demonstrate that uranine is transported between the injection well $\mathrm{B} 1$ and monitoring wells B7 and B8. The first arrival and peak concentration times and concentrations, provided in Table 1, indicate that the average velocity between B1 and B7, $20 \mathrm{~m}$ away, is significantly greater than between B1 and B8, $10 \mathrm{~m}$ away. Furthermore, the results of the Whole-well \#2 test demonstrated that the maximum concentration of tracer reaching B7 can be greater than at B8, despite the fact that it is farther from the injection point. These data provide an insight into the variability of both the deposits underlying the test

Table 1 Whole well, low flow and downhole fluorometer tracer test results for the Dornach test site, Germany

\begin{tabular}{|c|c|c|c|c|c|c|}
\hline $\begin{array}{l}\text { Test/observa- } \\
\text { tion well }\end{array}$ & $\begin{array}{l}\text { Sampling depth } \\
(\mathrm{mBTOC})^{1}\end{array}$ & $\begin{array}{l}\text { Starting conc } \\
\mathrm{Co}^{2}(\mathrm{ppb})^{3}\end{array}$ & $\begin{array}{l}\text { First arrival } \\
\text { (hours) }\end{array}$ & $\begin{array}{l}\text { Peak conc } \\
\text { time (hours) }\end{array}$ & $\begin{array}{l}\text { Peak relative conc } \\
(\mathrm{C} / \mathrm{Co})\end{array}$ & Comment \\
\hline \multicolumn{7}{|l|}{ Whole well \#1 } \\
\hline & Whole well & $4.55 E+03$ & 2.46 & 5.31 & 1.76 E-04 & Whole well sampled \\
\hline B8 & Whole well & $4.55 \mathrm{E}+03$ & 2.09 & 4.39 & 3.13 E-04 & Whole well sampled \\
\hline \multicolumn{7}{|l|}{ Whole well \#2 } \\
\hline B7 & Whole well & $4.16 \mathrm{E}+03$ & 3.13 & 6.04 & 3.04 E-04 & Whole well sampled \\
\hline B8 & Whole well & 4.16 E+03 & 3.13 & 5.88 & $2.15 \mathrm{E}-04$ & Whole well sampled \\
\hline Low flow \#1 & 5.5 & $2.21 \mathrm{E}+05$ & 2.58 & 3.83 & $2.82 \mathrm{E}-05$ & $\mathrm{Q}^{6}=0.78 \mathrm{~L} / \mathrm{min}$ \\
\hline \multirow[t]{3}{*}{ B8 } & 8.65 & $2.21 \mathrm{E}+05$ & $\mathrm{~N} / \mathrm{D}^{5}$ & $\mathrm{~N} / \mathrm{D}^{5}$ & $\mathrm{~N} / \mathrm{D}^{5}$ & $\mathrm{Q}^{6}=0.92 \mathrm{~L} / \mathrm{min}$ \\
\hline & 12 & $2.21 \mathrm{E}+05$ & 3.08 & 5.83 & $2.46 \mathrm{E}-04$ & $\mathrm{Q}^{6}=0.56 \mathrm{~L} / \mathrm{min}$ \\
\hline & 14 & $2.21 \mathrm{E}+05$ & $\mathrm{~N} / \mathrm{D}^{5}$ & $\mathrm{~N} / \mathrm{D}^{5}$ & $\mathrm{~N} / \mathrm{D}^{5}$ & $\mathrm{Q}^{6}=0.56 \mathrm{~L} / \mathrm{min}$ \\
\hline Low flow \#2 & 4.5 & $2.15 \mathrm{E}+05$ & 1.97 & 3.97 & $2.82 \mathrm{E}-05$ & $\mathrm{Q}^{6}=0.79 \mathrm{~L} / \mathrm{min}$ \\
\hline \multirow[t]{3}{*}{ B8 } & 11 & $2.15 \mathrm{E}+05$ & 3.14 & 6.14 & 4.07 E-04 & $\mathrm{Q}^{6}=1.31 \mathrm{~L} / \mathrm{min}$ \\
\hline & 12 & $2.15 \mathrm{E}+05$ & 3.19 & 5.93 & $5.55 \mathrm{E}-04$ & $\mathrm{Q}^{6}=0.96 \mathrm{~L} / \mathrm{min}$ \\
\hline & 13 & $2.15 \mathrm{E}+05$ & 3.27 & 6.05 & 3.45 E-04 & $\mathrm{Q}^{6}=1.21 \mathrm{~L} / \mathrm{min}$ \\
\hline Downhole \#1 & $3.0-14.5$ & $1.91 \mathrm{E}+05$ & 3.12 & 6.52 & 1.53 E-03 $(11.85)^{8}$ & Main arrival zone \\
\hline B8 & $\mathrm{mBGS}^{7}$ & $1.91 \mathrm{E}+05$ & 3.52 & 26.54 & $1.31 \mathrm{E}-05(4.75)^{8}$ & Secondary arrival zone \\
\hline Downhole \#2 & $3.0-14.5$ & $1.86 \mathrm{E}+05$ & 2.53 & 7.50 & 5.05 E-04 $(11.97)^{8}$ & Main arrival zone \\
\hline B8 & $\mathrm{mBGS}^{7}$ & $1.86 \mathrm{E}+05$ & 3.02 & 4.01 & 2.85 E-05 $(4.63)^{8}$ & Secondary arrival zone \\
\hline
\end{tabular}


site and trajectories of groundwater flowing through these deposits. Both these phenomena reflect the variation in mass transport conditions that may occur in porous aquifers both laterally and with time. However, the results provide no information on the vertical variability of tracer arrivals along the screened intervals of the monitoring wells. In contrast, the results of the Low flow \#1 and Low flow \#2 tests clearly demonstrate that, depending on the depth at which samples are collected, differing breakthrough curves may be obtained from B8. The data from Low flow \#1 display this phenomenon particularly well. The sample pump set at $12 \mathrm{mBGS}$ detected the highest concentrations of uranine. On the other hand, samples collected using the pump set at 14 mBGS contained no detectable quantities of tracer. Samples collected from the remaining two sampling points contained uranine but in lower concentrations (a breakthrough curve could not be confidently generated using samples collected at 8.65 mBGS as concentrations observed were too close to the detection limit of the fluorometer used).

It is notable that tracer first arrival and peak concentration times at 5.5 mBGS were earlier than those observed at $12 \mathrm{mBGS}$ during Low flow \#1. Moreover, the results from Low flow \#2 for observation well B8 are consistent with the results of Low flow \#1 and reflect the variation in tracer concentration with depth. Once again, uranine concentrations at the sampling point, set at 4.5 mBGS, are detectable but are over an order of magnitude lower than those sampled in the zone 1113 mBGS. In this latter zone, tracer concentrations are highest at $12 \mathrm{mBGS}$, while those at $13 \mathrm{mBGS}$ are lowest.

Tracer tests completed using the downhole fluorometer show that tracer occurs in a discrete depth interval in B8. Profiles generated using depth and concentration data show a distinct peak of tracer occurrence at approximately $12 \mathrm{mBGS}$ in both tests. The distribution of tracer around this zone varies between the two tests. Measurable concentrations of uranine were noted between 7.5 and 12.0 mBGS during Downhole \#1. In contrast, measurable concentrations were notable between 10.5 and $12.5 \mathrm{mBGS}$ during Downhole \#2, although the location of the zone of peak concentration remained consistently around 12 mBGS during both tests. Figure 7 presents images summarising breakthrough curves observed with depth through time for both Downhole \#1 and Downhole \#2 for the 7-14 mBGS interval, where high tracer concentrations were observed. The images differ in that the results of the earlier test, Downhole \#1, indicated that tracer was present over a larger depth interval and at higher concentrations compared to the data collected during Downhole \#2. This is suspected to be a consequence of differing flow dynamics in the well during the two tests, presumably due to a different groundwater flow regime in the aquifer during each experiment.

Table 1 also summarises the results of tracer tests Downhole \#1 and Downhole \#2 for B8. A secondary zone of tracer occurrence at between approximately 4.0 5.0 mBGS was detected in the profiles during Downhole $\# 1$ and Downhole \#2. The first significant concentrations

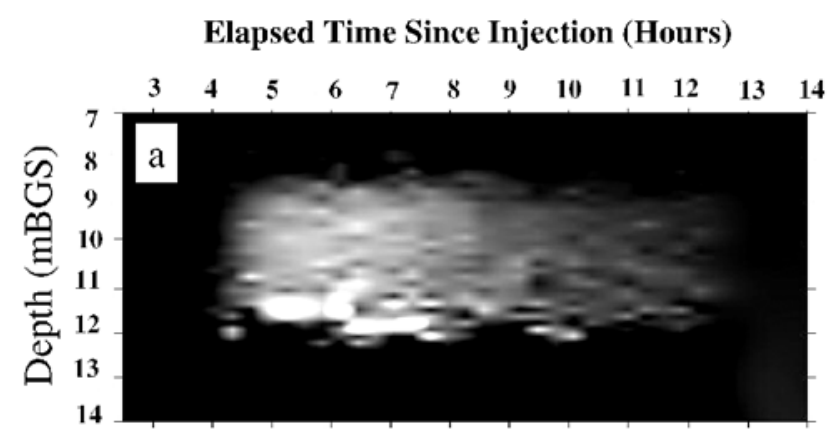

Elapsed Time Since Injection (Hours)

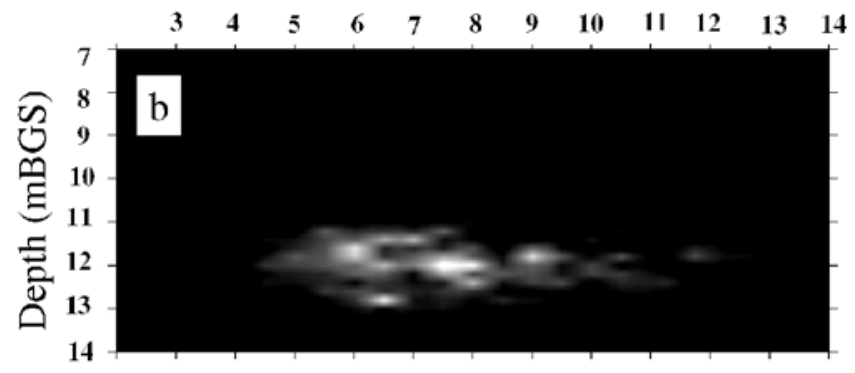

Fig. 7 Relative tracer concentration versus depth measured at half hourly intervals at observation well B8, Dornach test site. Maximum relative concentrations observed shown in white. a Downhole \#1, measured 27-28 June 01 (max tracer C/Co $\left.1.53 \times 10^{-3}\right)$, b Downhole \#2, measured 7-8 August 2002 (max tracer C/Co $\left.5.05 \times 10^{-4}\right)$

of uranine are apparent in this shallower zone at approximately the same time as in the deeper zone of tracer occurrence. However, peak concentration time is earlier than that observed at depth, although the peak concentration observed relative to that at $12 \mathrm{mBGS}$ is over an order of magnitude lower. These results are consistent with those observed during Low flow \#2. Tracer was also noted at this depth interval during Downhole \#1, although the time of first arrival was approximately $0.5 \mathrm{~h}$ later than that observed at depth, and occurred at a slightly shallower depth. Similarly peak concentration detection time was significantly later in the shallower zone than that observed at depth.

It is noteworthy that the Downhole \#1 and Downhole \#2 tracer concentration profiles, measured across the 7 14 mBGS interval, display a consistently high tracer concentration at $12 \mathrm{mBGS}$ with maximum concentrations occurring approximately at this depth during both tests. Furthermore, this phenomenon was apparent during the recession phase of the breakthrough curve, i.e. concentrations remain greatest at approximately $12 \mathrm{mBGS}$ even though whole well concentrations were declining. These observations are consistent with the results of low flow monitoring during Low flow \#2, where maximum tracer concentrations were also observed at 12 mBGS .

Uranine concentration profiles generated from single well dilution test results in B8 are consistent with the results of whole well tracer tests in that they suggest that groundwater flow rates through B8 may exceed $80 \mathrm{~m} /$ day 


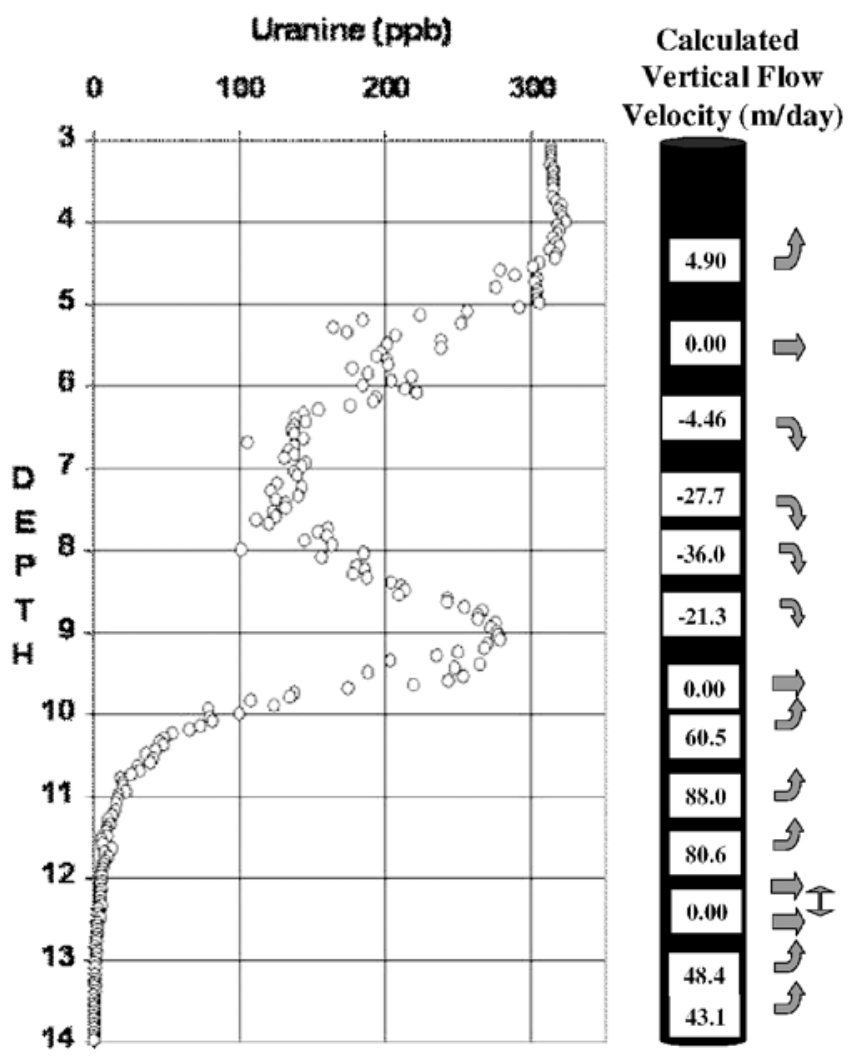

Fig. 8 Single well dilution test profile of uranine concentration measured in well B8 using the downhole fluorometer, 10 August 2002. Measurements were taken between 4 and 11 min after tracer injection. Arrows on the right-hand side of the plot indicate points of measurement and direction of vertical flow in the well

(See the Modelling section below). Between 3 and 11 min after tracer injection along the entire screened interval, the tracer has declined to between approximately 80 and $0.05 \%$ of its original concentration in the zone between 6 and $14.5 \mathrm{mBGS}$. The concentration profile observed is provided in Fig. 8. It is noteworthy that the concentration declines along the entire screened interval, with a notable peak between 8 and $10 \mathrm{mBGS}$. This pattern is consistent for all test repetitions in B8 with a variability of approximately $10 \%$ around the average measured concentration.

Figure 8 also summarises the results of the vertical flow measurements. These measurements indicate that vertical flow gradients vary in magnitude and direction with depth in B8. Notably, vertical flow data show that the peak observed at approximately $9.5 \mathrm{mBGS}$ during single well dilution tests corresponds to a zone where upwelling and downflowing well water converge, and where flow becomes horizontal. These results indicate that well water flows into this zone before discharging to the aquifer. This situation contrasts with measurements made in the upper part of the well at approximately $5.5 \mathrm{mBGS}$ which indicate that water enters the well at this level from the aquifer before flowing both upwards and downwards within the well.
Furthermore the vertical flow data indicate that the situation is more complex toward the base of the well. Well water flows upward close to the base of the well and the rate of flow gradually increases approaching approximately $12.5 \mathrm{mBGS}$. Test data indicate that no vertical flow occurs between 12 and 12.5 mBGS suggesting that it is a zone of horizontal flow. Measurements in the water column above this zone suggest that water flows upward once again to the horizontally convergent flow zone at 9.5 mBGS. The absence of indicators of vertical flow at 12.0 and $12.5 \mathrm{mBGS}$ is unusual since upwelling water occurs on either side of this zone. This suggests that a pressure gradient is present across the horizontally flowing zone and vertical flow phenomena should be observed. However, these phenomena are absent. A thin divergent flow zone present in the 12.0-12.5 mBGS interval could generate sufficient pressure to act as a hydraulic barrier to prevent upwelling water from crossing the 12.0-12.5 mBGS zone. As the results of the vertical flow tracer testing indicate that none of the injected tracer reached the sonde's measurement cell, the downwardflowing water would need to start flowing horizontally once again and leave the well before the tracer could enter into the fluorometer's sampling chamber. Such a zone is proposed to occur between 12.0 and 12.5 mBGS between the two vertical flow measurement points. The suspected zone was set at $12.3 \mathrm{mBGS}$ in the numerical model of the well water flow regime. This depth corresponds to the zone where sharp declines in uranine concentration were observed during Downhole \#1.

\section{Modelling}

Figure 9a presents the results of the well water flow model produced for B8. The data show that the calibration parameter values used can adequately reproduce the observed data within the constraints specified. The values of $q(z)_{\mathrm{h}}$ selected are presented in Fig. $9 \mathrm{~b}$ as a profile with depth. The horizontal specific fluxes calculated using the numerical model are the velocities of water leaving the well screen for each depth interval. Using the constraints imposed in Eq. (2), the velocities of the water entering the well can be back calculated when vertical flow rates are known. The entrance velocities are also presented in a depth profile in Fig. 9b.

Figure 9c graphically represents the results of the tracer arrival simulation in the well using the hydraulic parameters determined from the model calibration of single well dilution test data.

\section{Discussion}

The results of the laboratory experiments demonstrate that the fluorometer is capable of detecting fluorescent tracer in a water column with an accuracy of plus or minus $20 \mathrm{~cm}$, despite temporary storage and mixing effects in the borehole caused by sonde movement. The consistent 
Fig. 9 Numerical modelling results for well B8, Dornach test site. All depths in metres below ground surface. a Observed and simulated single well dilution test results (measured between 4 and 11 min after tracer injection), $\mathbf{b}$ profile of horizontal specific fluxes entering and exiting the well, c observed and simulated tracer arrival concentration profiles at 12 $12.5 \mathrm{mBGS}$ simulated using the numerical model

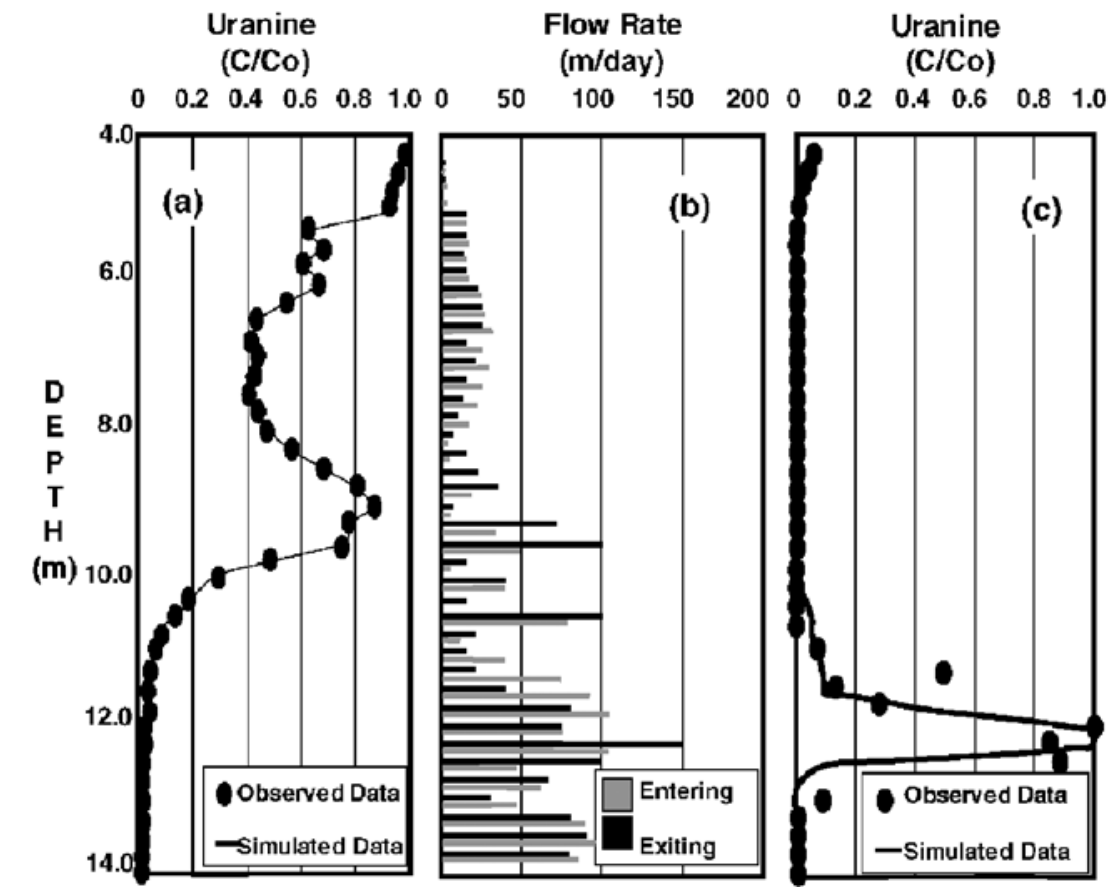

occurrence of low/high concentration points at the zone of active flow during respective well dilution tests/tracer arrival tests indicate the mobile downhole fluorometer is effective at detecting preferential flow zones. However, the process of identifying preferential flow zones is more complicated in wells where water flows vertically as vertically flowing water distributes the tracer through the water column by advection. Nonetheless, consistent peak concentration measurements at the depth of tracer entry into the borehole still permit these zones to be identified.

Tests employing the downhole fluorometer to measure vertical flow rates have also demonstrated that the meter can determine the magnitude and direction of vertical flow. This method can provide a cost-effective and portable means of determining vertical flow rates in shallow hydrogeological systems when alternative vertical-flow measurement devices are not available.

The various tracer breakthrough curves generated from whole-well tracer test data at Dornach demonstrate that the deposits underlying the site exhibit spatial and temporal variations in mass transport properties. However, the continuous recirculation method used to monitor for uranine prevented identification of the contributing horizons along the 12-m-long screened interval in B8. Low flow sampling for tracer at different levels in this well during Low flow \#1 demonstrated that the tracer's arrival in the well was not uniform and that different breakthrough curves could be observed at different levels in the well. In particular, the contrast between samples collected at 12 and 14 mBGS in B8 during Dornach \#4 demonstrates the extreme variability in tracer concentration that can be observed over short distances in wells with longscreened intervals.

Following injection in B1, fluorescent tracer monitoring in B8, using the mobile downhole fluorometer al- lowed zones of tracer occurrence in the observation well to be identified. The results of both Downhole \#1 and Downhole \#2 indicated that uranine was detected in two distinct zones separated from each other by an interval where no tracer was apparent. Concentrations were greatest in the 9.0-12.5-mBGS zone, while those in the shallower 4.5-mBGS zone were approximately an order of magnitude lower. The earlier, but lower, peak concentrations observed at the shallower depth during Downhole \#2, suggest that the tracer here may be the lateral edge of a more rapidly flowing finger of the tracer plume.

Single well test results and vertical flow test results indicate that groundwater containing no detectable quantity of tracer entered B8 during Downhole \#2. Indeed, numerical modelling results simulating the concentrations observed during single-well dilution tests indicate that the velocities of tracer-free water entering observation well B8 at numerous horizons are comparable to those in the horizon supplying tracer to the well at approximately $12 \mathrm{mBGS}$. These data suggest that the groundwater entering B8 at various levels has not flowed via the fully-penetrating injection well B1, but rather arrived at $\mathrm{B} 8$ via alternative routes. Conversely, the breakthrough tracer data obtained from measurements taken at 4.0-5.0 mBGS indicate that some groundwater flowed through B1 and picked up tracer en route. However, this water did not pass directly through observation well B8. Both lines of evidence suggest that groundwater flow directions followed in the gravel deposits underlying the Dornach test site are not uniform, but vary with depth. Moreover, this hypothesis is consistent with the tracer responses observed in $\mathrm{B} 7$ compared to those in $\mathrm{B} 8$, during Whole well test \#1 and Whole well test \#2. 
The forms of the tracer distribution profiles observed in B8 are similar to those noted during tracer arrival tests generated by the fluorometer using the Laboratory borehole apparatus, when a vertical flow regime is operating. The consistently high peak concentrations at approximately $12 \mathrm{mBGS}$ at B8 suggest that this is the zone of tracer arrival. Tracer entering the well at this point is subsequently redistributed in the well by vertical flow gradients while being diluted by tracer-free water. These data thus imply that the zone supplying tracer to B8 is thinner than the zone of uranine occurrence in the well. Indeed model simulations of tracer arrival bear a strong similarity to tracer arrival patterns observed in the field and contain tracer at similar concentrations and at similar depths to those observed (Fig. 9c). During this simulation, the thickness of the zone of tracer arrival was set at $0.5 \mathrm{~m}$. This result emphasises the importance of aquifer heterogeneity in the transport of groundwater tracers to observation wells since relatively minor amounts of tracer occurring in B8 can be attributed to tracer arriving from alternate zones.

\section{Conclusions}

Laboratory-based investigations of the application of a mobile downhole fluorometer demonstrated that the meter can be used to detect zones of preferential groundwater flow and tracer arrival in a well. Moreover, by modifying the fluorometer to allow tracer injection at a fixed separation interval in a well, the apparatus may be used to determine the direction and magnitude of vertical flow gradients. Applications of these techniques at a sand and gravel aquifer test site demonstrated that the meter may be used to understand well water flow dynamics and detect zones of tracer arrival. When the results of single well dilution tests, vertical flow testing and tracer arrival tests are considered together, the well water flow regime may be numerically modelled. Modelling results for a fully penetrating observation well indicated that during tracer arrival tests, tracer entered the well in a zone no more than $50 \mathrm{~cm}$ thick and was spread over a larger screened interval by vertical gradients. Entrance and exit velocities demonstrate that water flowed into the well at comparable velocities from other horizons but did not contain tracer. These data indicate that groundwater flow trajectories in the aquifer varied with depth.
Acknowledgements This project was funded by the Swiss National Science Foundation (Grant No. FN-20-061370.00). Use of the Dornach Test Site was provided by the GSF, Neuherberg. The authors wish to express their thanks to Mr. Micheal Stökl for his technical assistance during the tracer tests at the site.

\section{References}

Drost W, Klotz D, Koch A, Moser H, Neumaier F, Rauert W (1968) Point dilution methods of investigating groundwater flow by means of radioisotopes. Water Resour Res 4(1):125-146

Hutchins SR, Acree SD (2000) Groundwater sampling bias observed in shallow conventional wells. Ground Water Monit Rem 20(1):86-83

Jones I, Lerner D (1995) Level-determined sampling in an uncased borehole. J Hydrol 17:291-317

Kaleris V, Hadjitheodorou C, Demertracopoulos AC (1995) Numerical simulation of field methods for estimating hydraulic conductivity and concentration profiles. J Hydrol 71:319-353

Kass W (1997) Tracing technique in geohydrology. Balkema, Rotterdam, pp 581

Kennedy K, Muller I, Schnegg P, Rossi P, Koezel R (2001) Characterisation of the Kappelen Groundwater Research Site (BE), Switzerland and preliminary bacteriophage and solute tracer component responses. Beitr Hydrogeol 52:158-180

Müller J, Seiler KP (2001) The role of DOC and EDTA on the remobilisation of heavy metals in carbonate groundwater. In: Seiler KP, Wohnlich S (eds) New approaches to characterising groundwater flow, vol 1. Balkema, Lisse, pp 149-152

Price M, Williams A (1993) The influence of unlined boreholes on groundwater chemistry: a comparative study using pore-water extraction and packer sampling. J Inst Water Environ Manage 7(6):651-659

Rapp MC, Fulda C, Schaefer W, Kinzelbach W (1998) The dual pumping technique (DPT) for level-determined sampling in fully screened groundwater wells. J Hydrol 207:220-235

Rushton KR, Howard KWF (1982) The unreliability of open observation boreholes in unconfined pumping tests. Groundwater 20:546-550

Seiler KP (1988) Mechanical filtration mechanisms for EColi in Quaternary gravels, Upper Bavaria (in German). Z Dt Geol Geseu 139:475-484

Schirmer M, Jones I, Teutsch G, Lerner D (1995) Development and testing of multiport sock samplers for groundwater. J Hydrol 171:239-287

Schnegg P, Bossy F (2001) Sonde for downhole measurement of water turbidity and dye tracer concentration. In: Seiler K P, Wohnlich S (eds) New approaches to characterising groundwater flow, vol 1. Balkema, Lisse, pp 149-152

Zahn MT, Seiler KP (1992) Field studies on the migration of arsenic and cadmium in a carbonate gravel aquifer near Munich (Germany). J Hydrol 133:201-214 